\title{
REVITALISASI PENDIDIKAN ASWAJA AN NAHDLIYAH (KE-NU-AN) DALAM MENANGKAL FAHAM RADIKALISME DI SMK AL-AZHAR MENGANTI GRESIK
}

\author{
Muhamad Arif \\ STAI Al-Azhar Menganti Gresik, Jawa Timur, Indonesia \\ e-mail: muhamadarif070593@gmail.com
}

\begin{abstract}
The rise of radicalism ideology, became the main work of the madrasa as a guardian of Islamic ideology that rahmatan lil alamin. A unique phenomenon was found by researchers in an educational institution, namely in the Al-Azhar Menganti Vocational School (SMK), a middle-level educational institution that is included in the shelter of the Darul Ihsan Menganti Islamic boarding school foundation. Al-Azhar Menganti Vocational School (SMK), at the beginning of the admission of new students, each new student was given material on religiousness (NU-an), and there was ta'lim muta'alim in the style of the cottage for Nahdlatul Ulama. In addition, the NU studies were a study that was the closing point at the end of each semester, as one of the objectives was to achieve Islam rahmatan lil alamin and efforts to win the rise of the radical movement. This study uses qualitative research methods that produce descriptive data in the form of written or oral words from people and behaviors that can be seen during the research process. Related to this is arranged on the background of this individual as a whole (intact) without any engineering. Some of the main capital invested in Al-Azhar Vocational School students, as a real effort to counteract the amount of radicalism in the world of education, one of which is by incorporating self-education into the school curriculum as a local substitute. In addition to the implementation sought by the al-Azhar Menganti Vocational School, it does not include several limitations in implementing Aswaja education (Ke-NU-an), which is translated, namely the number of books abroad Aswaja Nahdliyyin (Ke-NU-an), in the name of Aswaja (Ke-NU-an).
\end{abstract}

Keywords: Education; Radicalism Ideology; Aswaja ideology

Abstrak: Maraknya ideologi radikalisme, menjadi pekerjaan utama madrasah sebagai pengawal ideologi islam yang rahmatan lil alamin. fenomena unik ditemukan peneliti pada suatu lembaga pendidikan, yaitu tepatnya pada Sekolah Menengah Kejuruan (SMK) Al-Azhar Menganti, sebuah lembaga pendidikan tingkat menengah yang masuk dalam naungan yayasan pondok pesantren Darul Ihsan Menganti. Sekolah Menengah Kejuruan (SMK) Al-Azhar Menganti, pada awal penerimaan siswa baru, setiap siswa baru diberikan materi tentang keaswajaan (Ke-NU-an), dan adab ta'lim muta'alim ala pondok pesantren Nahdlatul Ulama'. Selain itu kajian-kajian Ke-NU-an menjadi kajian yang menjadi penutup pada setiap akhir semester, sebagai salah satu tujuanya adalah mencapai islam rahmatan lil alamin serta upaya menangkan maraknya gerakan radikalisme. Penelitian menggunakan metode kualitatif agar dapat menghasilkan data deskriptif berupa tulisan atau lisan dari sumber data yang diamati selama proses penelitian. pendekatan ini diarahkan pada latar belakang individu tanpa adanya rekayasa, yaitu dengan mencantumkan secara utuh. Beberapa modal utama yang ditanamkan pada siswa SMK Al-Azhar, sebagai upaya nyata dalam menangkal banyaknya faham radikalisme pada dunia pendidikan, salah satunya adalah dengan Memasukkan pendidikan aswaja ke dalam kurikulum sekolah sebagai muatan lokal. Selain penerapan yang diupayakan oleh pihak SMK al-Azhar Menganti, tidak menutup kemungkinan terdapat beberapa hambatan dalam menerapkan pendidikan Aswaja (Ke-NU-an), diantaranya, yaitu Banyaknya buku-buku diluar faham Aswaja Nahdliyyin (Ke-NU-an), namun mengatasnamakan faham Aswaja (Ke-NU-an).

Kata Kunci: Pendidikan; Ideologi Radikal; Ideologi Aswaja 


\section{PENDAHULUAN.}

Kajian tentang Islam di era millenial umumnya berkonsentrasi pada sebuah tipikal baru yaitu gerakan modernism yang sangat beragam. Pada saat ini semua kaum muslimin terus menjalani hidup di dunia tradisi, (Nasr, 2003, p. 21) meskipun banyaknya serangan yang terjadi terhadap pandangan tradisional di era modern. Munculnya gerakan modernism tak dapat dipisahkan dengan sejarah yang berawal dari wafatnya Nabi Muhammad SAW, menjadi awal mula timbulnya perpecahan dan munculnya aliran-aliran dalam sekte Islam, misalnya Syiah, Khawarij, Jabariyah, dan Qodariayah (Muctoboh et al., 2017).

Sebagaimana pembahasan tentang aliran-aliran modern dalam Islam tidak dapat dilepaskan dengan keberadaan aliran sunni atau lebih di kenal dengan Ahlu Sunnah Wal Jama'ah(ASWAJA). Kata Ahlu Sunnah Wal Jama'ah adalah gabungan dari kata Ahl as-sunnah dan ahljamaah. Aliran Ahlu Sunnah Wal Jama'ah tidak terdapat pada zaman Nabi Muhammad SAW dan para sahabat. Karena istilah Ahlu Sunnah Wal Jama'ah pertama kali dipakai adalah pada masa pemerintahan khalifah Abu Ja'far al-Mansur (137-159 H/754-775 M) dan khalifah Harun Ar Rasyid yang keduanya adalah dari Dinasti Abbasiyah. Ahlu Sunnah Wal Jama'ah semakin Nampak pada khalifah al-Makmun (198-218 H/183-833 M) (Muctoboh et al., 2017, p. 90).

Definisi Ahlu Sunnah Wal Jama'ah adalah para sahabat Nabi Muhammad SAW yang mengikuti dengan baik dan berpegang teguh dengan jejak Nabi Muhammad SAW sampai hari kiamat. Predikat Ahlu Sunnah disematkan karena mereka mengambil dari Sunnah Rasulullah. Dan al-Jama'ah adalah meyakini kebenaran yaitu orang-orang yang berpegang teguh dengan sunnah, dari sahabat, tabi'in tabiut-tabiin (Waskito, 2012).

Dapat dicermati asal-usul istilah Ahlu Sunnah Wal Jama'ah adalah berawal dari salah satu hadis nabi Muhammad SAW, sebagai mana teks hadis adalah sebagai berikut:

$$
\begin{aligned}
& \text { افترقت اليهود على إحدى أو اثنتين وسبعين فرقة ، وافترقت النصارى على إحدى أو اثنتين وسبعين فرقة ، } \\
& \text { وستفترق أمتي على ثلاث وسبعين فرقةة، الناجياة منها واحدة والباقون هلكى. قيل: ومن الناجية ؟ قال: أهل } \\
& \text { السنة والجماعة. قيل: وما السنة والجماعة ؟ قال: ما انا عليه اليوم و أصحابها }
\end{aligned}
$$

Artinya: terpecah golongan yahudi menjadi 71 atau 72 golongan, sedangkan orang Nasrani menjadi 71 atau 72 golongan, dan umatku yaitu umat Rasul Muhammad akan menjadi 73 golongan. Sedangkan yang selamat hanyalah satu golongan karena golongan lain akan celaka. Ditanyakan 'Siapakah yang selamat itu?' Rasulullah SAW menjawab, 'Ahlusunnah wal Jama'ah'. Kemudian timbullah ditanyakan lagi, 'apakah yang disebut golongan assunah wal jama'ah itu?' Beliau menjawab, 'Golongan yang pada hari ini mengikutiku, dan beserta para sahabatku (Waskito, 2012).

Ahlu Sunnah Wal Jama'ah mempunyai landasan dalam mengambil suatu hukum, yaitu dari: al-Qur'an, Hadis, Ijma' dan Qiyas. Ciri-ciri Ahlu Sunnah Wal Jama'ah adalah dalam bidang aqidah adalah mengikuti, Imam Abul Hasan al-Asy'ari dan Imam Manshur al-Maturidzi. Di bidang fiqih, Ahlussunnah Wal Jama'ah mengikuti salah satu dari madzhab Abu Hanifah an-Nu'man, Imam Malik bin Anas, Imam Muhammad bin Idris Asy-Syafi'I dan Imam Ahmad bin Hanbal. Di bidang tasawuf, Ahlussunnah Wal Jama'ah mengikuti antara lain Imam al-Junaidi al-Baghdadi dan Imam al-Ghazali serta imam-imam yang lain (Ramli, 2011).

Pada bumi Nusantara istilah Ahlu Sunnah Wal Jama'ah, sangat melekat pada organisasi kemasyarakatan yang dipelopori oleh KH. M. Hasyim Asy'ari dan generasi muslim pada zamanya dengan berdirinya organisasi Islam Nahdlatul Ulama'. Nahdlatul Ulama' sebagai Jam'iyah dinniyah sebuah wadah bagi para ulama' dan para pengikutnya, yang didirikan pada 16 rajab $1344 \mathrm{H} / 31$ Januari 1926. Dengan tujuan memelihara, melestarikan dan mengamalkan ajaran Ahlu Sunnah Wal Jama'ah yang menganut faham Ahlu Sunnah Wal Jama'ah baik dalam pengambilan suatu hukum dan bermadzab. Nahdlatul Ulama' bertujuan untuk ikut membangun dan mengembangakan insan dan masyarakat yang bertaqwa kepada Allah SWT, cerdas, terampil, berakhlak mulia, adil, tentram dan sejahtera dalam berbagai aspek kehidupan (Muzadi, 2007, p. 35).

Nahdlatul Ulama' sebagai organisasi kemasyarakatan mempunyai fikrah khusus dalam menyikapi berbagai permasalahan di lapangan. Pertama adalah fikrah tawassuthiyyah pola pikir modern artinya Nahdlatul Ulama' bersikap tawazun/seimbang dan I'tidal/moderat dalam 
menaggapi berbagai permasalahan yang terjadi. Kedua fikrah tasamuhiyah pola pikir toleran yaitu hidup berdampingan secara damai dengan pihak lain, meskipun akidah, cara pikir dan budayanya berbeda. Ketiga, fikrah Ishlahiyyah pola pikir reformatif yaitu perbaikan menuju kearah yang lebih baik. Keempat, fikrah Tathawwuriyah pola dinamis dalam merespon persoalan. Dan Kelima adalah fikrah Manhajiyah sebuah pola piker metodologis, kerangka berfikir yang mengacu pada manhaj yang telah ditetapkan oleh Nahdlatul Ulama' (Navis, Ramli, \& Anam, 2016, p. 76).

Bertolak dari fikrah Nahdlatul Ulama' dengan menyuguhkan Islam Rahmatan lil alamin, terdapat fenomena baru yang berada di bumi nusantara yaitu maraknya faham radikal yang megatasnamakan Islam sebagai mana pemaparan Umar tentang melacak akar radikalisme di Indonesia, yaitu radikalisme Islam muncul sebagai respons sejarah dan radikalisme Islam sebagai sebuah proses historis. Seperti masuknya Gerakan yang seperti Wahabi di Arab Saudi dan Ikhwanul Muslimin di Mesir. Munculnya Hizbut-Tahrir dari Yordania (Umar, 2010). Radikalisme juga disampaikan Hilmy dalam radikalisme agama dan politik demokrasi pasca orde baru, yang menjelaskan bahwa kalangan radikal ekstrem, menolak dengan jelas terhadap sistem demokrasi dan mengatakan thogut terhadap pemerintahan Indonesia. Sedangakan kelompok radikal lunak berargumentasi dengan norma-teologis dan kajian-kajian secara mendalam tentang kebobrokan sistem demokrasi serta melakukan penolakan melalui keengganan mereka berjuang melalui sistem parpol. (Hilmy, 2015). Suatu hal yang tidak seharusnya terjadi, karena radikalisme yang seharusnya di hindari namun mempunyai banyak pengikut seperti beberapa organisasi seperti: Jama'ah Islamiyah (JI, 1993), Majelis Mujahidin Indonesia (MMI, 1999), atau Jama'ah Anshorut Tauhid (JAT, 2008), Front Pembela Islam (FPI), Front Pemuda Islam Surakarta (FPIS) Hizbut Tahrir Indonesia (HTI), Laskar Jundullah, Laskar Umat Islam Surakarta. Seperti pemaparan dari Ahyar, yang menjelaskan tentang Radikalisme yang tidak hanya membahas tentang kesalahan ideologi agama yang masyarakat terima, radikalisme menggambarkan sebuah fenomena sosial masyarakat yang begitu kompleks meliputi berbagai unsur, mulai persoalan keagamaan, kesenjangan sosial, politik, pendidikan, penegakan hukum hingga masalah perjuangan terhadap identitas tertentu (Ahyar, 2015).

Maraknya faham radikal juga di paparkan oleh Inbar dalam bukunya, yang mengatakan bahwa Radikalisme Islam berkontribusi terhadap kekerasan dan perpecahan di dalam dunia Islam itu sendiri.

"Islamic radicalism contributes to violence and division within the Islamic world it self, as the ongoing conflict in Iraq demonstrates. In short, radical Islam poses a challenge to the statebased and broadly secular international system that has been in place since the seventeenth century, in addition to the states and societies that make up this system. Ideologically, Islamism has replaced communism and fascism as the greatest threat to liberal democratic ideals by which most states in the West abide and which most other states rhetorically espouse."(Inbar \& Frisch, 2008, p. 1)

Ideologi Islam radikal, menjadi sebuah ideologi yang seharusnya dicegah sedini mungkin kepada masyarakat Indonesia, terutama para pelajar. Penanaman ideologi Keaswajaan sebagai pioner dalam menangkal masifnya gerakan radikalisme, seperti hasil penelitian Naim tentang pengembangan pendidikan aswaja sebagai strategi deradikalisasi, sebagaimana di SMA Diponegoro Tulungagung strategi yang disusun dalam memberikan pemahaman kepada para siswa. Yaitu dengan penyampaian materi secara klasikal, di sekolah dan pembiasaan ibadah (Naim, 2015). Hal senada juga dikuatkan dengan hasil penelitian Suharto tentang potret pendidikan moderat seperti Muhammadiyah dan NU memiliki gagasan untuk mencanangkan pendidikan Islam moderat melalui perjuangan teologis-kulturalnya masing-masing sebagai penangkal gerakan radikalisme (Suharto, 2014).

Semakin maraknya ideologi radikalisme, menjadi peran utama madrasah sebagai pengawal ideologi islam yang rahmatan lil alamin, berawal dari sinilah penulis melakukan observasi pemula, dari fenomena yang unik pada suatu lembaga pendidikan, yaitu tepatnya pada Sekolah Menengah Kejuruan (SMK) Al-Azhar Menganti, sebuah lembaga pendidikan tingkat menengah yang masuk dalam naungan yayasan pondok pesantren Darul Ihsan Menganti. Sekolah Menengah Kejuruan (SMK) Al-Azhar Menganti, pada awal penerimaan siswa baru, setiap siswa baru diberikan materi tentang keaswajaan (Ke-NU-an), dan adab ta'lim muta'alim ala pondok pesantren Nahdlatul Ulama'.

\author{
J-PAI: Jurnal Pendidikan Agama Islam \\ Vol. 5 No. 1 Juli-Desember 2018 \\ Homepage: http://ejournal.uin-malang.ac.id/index.php/jpai/
}


Selain itu kajian-kajian Ke-NU-an menjadi kajian yang menjadi penutup pada setiap akhir semester, sebagai salah satu tujuanya adalah mencapai Islam rahmatan lil alamin dan menangkan maraknya gerakan radikalisme.

Dari fenomena di atas, maka penulis tergelitik untuk melakukan riset secara spesifik di SMK al-Azhar Menganti Gresik, tentang bagaimana penerapan pendidikan aswaja an nahdliyah (Ke-NUan) dalam menangkal faham radikalisme, serta apa saja yang menjadi penghambat dalam menerapkan pendidikan Aswaja annahdliyah (Ke-NU-an) di SMK al-Azhar Menganti Gresik.

\section{NAHDLATUL ULAMA (ASWAJA)}

Pendirian organisasi Nahdlatul Ulama (NU) sebagai respon dikala Arab Saudi yang diduduki penguasa baru dengan faham Wahabi, yang telah berlebih-lebihan dalam menerapkan pemurnian ajaran Islam. Serta upaya penghapusan perkembangan madzab empat, selain madzab Wahabi. Besarnya faham Wahabi memunculkan muktamar khilafah yang berada di Arab Saudi, di saat itulah cikal bakal NU didirikan, dengan nama komite hijaz, sebagai harapan untuk mengikuti muktamar khilafah di arab Saudi. Setelah muktamar di arab Saudi, Komite hijaz digantikan dengan organisasi bernama Nahdlatul Ulama (NU) yang didirikan pada 31 januari 1926, NU didirikan oleh KH. M. Hasyim Asy'ari, NU sebagai jam'iyyah dinniyah ijtima'iyah yang dibentuk sebagai wadah perjuangan para ulama dan pengikutnya. Nahdlatul Ulama (NU) mempunyai dua wajah di masyarakat. Pertama, wajah jam'iyyah, sebagai organisasi dengan formal struktural yang mengikuti organisasi modern. Kedua, wajah jama'ah yaitu kelompok ideologis kultural yang mempunyai pandangan keagamaan dan budaya ala NU. Keduanya menjadi penyumbang kader penerus Nahdlatul Ulama (NU), dalam berbagai aspek baik jam'iyyah maupun jama'ah (Muzadi, 2007, p. 36).

Nahdlatul Ulama (NU) organisasi yang menganut faham Ahlu Sunnah Wal Jama'ah, sebuah pola pikir yang mengambil jalan tengah antara ekstrem rasionalis (mu'tazilah) dan kaum ekstrem literalis (salafi/wahabi). Maka dari itu corak pemikiran NU tidak hanya terpaku pada sumber alQur'an dan Hadis, NU menambahkan kemampuan akal dan realitas empiric atau lebih sering di kenal dengan ijma' dan qiyas. Serta dalam bermadzab bidang teologi NU mengikuti Imam Abu Hasan al-Asy'ari dan Imam Abu Mansur al-Maturidi. Serta dalam bidang fikih NU cenderung mengikuti Imam Syafi'i. Serta mengakui tiga madzab lainnya, yaitu: Imam Abu Hanifah, Imam Malik dan Imam Ahmad bin Hambal. Sebagaiman yang tergambar dalam lambang NU yang berlambang bintang 4. Sementara dalam bidang tasawwuf NU mengembangakan metode Imam al-Ghozali dan Imam Junaidi al-Baghdadi. Dengan integrasinya antara tasawuf dan syariat (Zuhri, 2010, pp. 108109).

Selain itu Nahdlatul Ulama (NU), menjadi organisasi Islam yang berada paling terdepan dalam mengawal eksistesi Negara Indonesia, sebuah organisasi keagamaan yang mampu di terima di berbagai masyarakat, baik kota maupun pedesaan, sebagaimana pemaparan, Robinson:

"The modernist Muslim organization Muhammadiyah had been 'matched' by the establishment of Nahdlatul Ulama (NU) in 1926 to represent 'traditionalist' Islam. In theological terms, the difference relates to the stance with regard to the interpretation of the classical Islamic texts, with $N U$ basing its teachings on the classical texts written in the first centuries following the death of the Prophet. Muhammadiyah, the parent organization of Aisyiyah, is a modernizing/reformist organization. In the Indonesian context, the important difference is that $N U$ embraces Sufi elements and the accommodation of Islam to local culture. Openness has allowed $N U$ to embrace new ideas, for example, issuing fatwa endorsing women riding bicycles and women's involvement in politics. $\mathrm{NU}$ is now the largest mass Islamic organization in Indonesia."(Robinson, 2009, p. 53)

Berdirinya Nahdlatul Ulama (NU) berdampingan dengan Muhammadiyah. NU berdiri pada tahun 1926 mewakili kaum tradisionalis Islam. Dalam istilah teologis, perbedaannya berkaitan dengan pendirian sehubungan dengan penafsiran teks-teks Islam klasik, karena NU mendasarkan ajarannya pada teks-teks klasik yang ditulis pada abad-abad pertama setelah wafatnya Nabi Muhammad SAW. NU sebagai organisasi yang merangkul unsur-unsur sufi dan akomodasi Islam dengan budaya lokal. Keterbukaan telah memungkinkan NU untuk merangkul ide-ide baru misalnya, mengeluarkan fatwa yang mendukung perempuan mengendarai sepeda dan keterlibatan perempuan dalam politik. NU sekarang adalah organisasi massa Islam terbesar di Indonesia.

J-PAI: Jurnal Pendidikan Agama Islam 
Organisasi Nahdlatul Ulama' (NU) bisa di bilang kiprahnya berhasil pada bidang pendidikan, karena jumlah madrasah meningkat sangat pesat selama kurun waktu 1920-1930 banyaknya cabang besar Nahdlatul Ulama (NU) yang mendirikan madrasah dan pesantren. Nahdlatul Ulama (NU) mendirikan lembaga yang mengkoordinasikan kegiatan-kegiatan pendidikan yaitu lembaga ma'arif NU. Ini adalah sebuah bukti kongkrit NU dalam mengawal ideologinya (Felay, 2003, p. 27).

\section{HASIL DAN PEMBAHASAN Faham Radikal}

Pembahasan tentang Islam radikal, bukan lagi menjadi pembahasan baru keberadan gerakan Islam radikal secara geografis tersebar di Timur Jauh, Asia Tenggara, Eropa, Afrika dan, tentu saja, Timur Tengah. Bahkan, hampir tidak ada wilayah di dunia di mana mereka tidak ada. Tujuan dari gerakan-gerakan ini berkisar dari penghapusan sistem internasional berbasis negara hingga penggulingan rezim hingga penggantian mereka oleh teokrasi. Sebagaimana pemaparan Finch dan Inbar:

"Radical Islamic movements are geographically dispersed throughout the Far East, Southeast Asia, Europe, Africa, and of course, the Middle East. In fact, there is scarcely a region on the globe where they do not exist. The goals of these movements range from the removal of state-based international systems to the overthrow of regimes to their replacement by theocracies. The violence they engender is rivaled today only by ethno-national movements. Islamism challenges the integrity of state regimes (Egypt, Jordan and India), the very existence of states (Israel and Lebanon), exacerbates relations between states directly (Iran-United States), and indirectly when states support and abet Islamic terror movements (Pakistan-India, Syria-Israel)" (Inbar \& Frisch, 2008, p. 1).

Karena munculnya faham radikal secara tidak langsung menolak aturan demokrasi yang berlaku di Indonesia. Adanya sistem demokrasi berawal dari dunia barat, yang notabenya sangat dilawan oleh faham Islam garis keras. Respon penolakan yang sagat beragam dari yang paling lunak sampai pada yang sangat ekstrem. Seperti meyebarnya penolakan secara lunak yang terbungkus dengan cara melakukan kajian-kajian empiris terhadap dunia-dunia barat, membongkar bobroknya system demokrasi, serta banyaknya deskriminasi terhadap kaum muslim minoritas di barat serta isu-isu lainnya. Sedangakn kaum radikal ekstrem cenderung memakai jalan kekerasan,seperti penyisiran tempat hiburan malam, penutupan secara paksa toko nasi ketika bulan ramadhan, penghancuran fasilitas. Bahkan bentor antar organisasi yang tidak sejalan dengan mereka dalam membentuk syariah Islam. Seperti sekelompok yang masuk pada anggota front pembela islam (FPI) (Hilmy, 2015).

Sebagaimana pemaparan dari Sahrasad dan Chaidar, tentang eksistensi faham radikal Islam, sebagai faham yang memandang bahwa memahami agama Islam secara mengakar jauh dan detail, itu lebih penting sebelum membuat rencana aksi yang cenderung mengarah kepada kekerasan. Dewasa ini kaum radikal baru Islam tidak merupakan gerakan yang homogen. Karena muslim radikal berupaya meletakkan rumah mereka sendiri dalam suatu tata-aturan yang berbeda sesuai dengan yang mereka persepsikan yaitu dalam pemahaman agama Islam. Tidak seperti adanya kaum fundamentalis yang terlalu parah dan keras, karena pada dasarnya kaum radikal merasa nyaman dengan bergesernya zaman pada saat ini (Sahrasad \& Chaidar, 2017, p. 365).

Tumbuhnya kaum terorisme di Indonesia berawal dari adanya faham radikal yang bertemu dengan faham fundamentalis Indonesia. Karena banyaknya kaum teroris adalah akar dari penggabungan dari inti ajaran fundamentalis dan radikal yang bertemu dalam sebuah titik temu yaitu perang melawan persepsi yang gagal yaitu presepsi tentang 'kezaliman'. Di Indonesia, kelompok teroris ini berjumlah kecil: (1) Jamaah Islamiyyah, dan (2) Darul Islam (terbatas pada faksi tertentu). Selain itu terdapat bentuk lain tentang berkembangnya faham terorisme yang mengatasnamakan Islam, terorisme terbentuk karena adanya tumpang tindih dari berkembangnya faham fundamentalisme dan paham radikalisme Islam. Secara pemikiran sangat perlu adanya pemisah untuk menghilangkan akar terorisme yaitu dengan tidak mempertemukan paham fundamentalisme Islam dan paham radikalisme Islam dalam satu wadah yang legal (Sahrasad \& Chaidar, 2017, p. 366), sebagaiman gambar di bawah ini: 
Gambar 1. Munculnya Faham Terorisme Akibat Bertemunya Faham Fundamentalis Dan Radikal

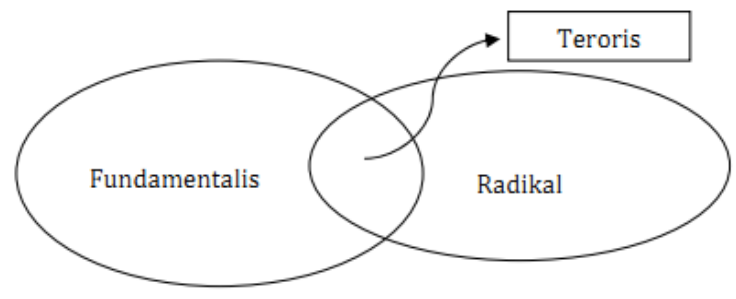

Sumber: (Sahrasad \& Chaidar, 2017)

Gambar di atas memperlihatkan tentang bagaimana anatomi pemikiran ideologis kaum teroris. Yang berakar dari faham fundamentalis dan radikal. Karena Islam radikal secara acak mendoktrin kepada manusia untuk mengambil nyawa dan melukai orang-orang dalam populasi yang belum tunduk pada Islam seperti yang meraka pahami atau yang mematuhi varian Islam lainnya. Kehidupan penganutnya sendiri juga dituntut untuk saling memaafkan. Berangkat dari pemahamn mereka bahwa faham Islam radikal sebagai syahid yang memiliki pahala yang tertinggi ketika mengikutinya. Sebagaimana pemaparan Inbar:

"Radical Islam randomly takes lives and maims people in populations that have not submitted

to Islam or that adhere to another variant of Islam. The lives of own adherents are also required

to be willingly forgone. Departure from this world as a shahid or martyr has ultimate merit"

(Inbar \& Frisch, 2008, p. 46).

Seperti menjamurnya gerakan islam radikal di Indonesia, suatu gerakan Islam yang berorientasi mewujudkan Negara Syariat Islam ini merupakan ancaman nyata bagi keberadaan Negara Kesatuan Republik Indonesia (NKRI) dan Pancasila. Bahkan juga menjadi ancaman bagu bagi kemajemukan bangsa Indonesia yang selama ini ditopang dari berbagai bahasa dan budaya yang berbeda-beda sebagai pondasi kestabilan bangsa Indonesia (Husna \& Yunus, 2016, p. 302). Dengan demikian maka perlu dilakukan sebuah upaya revitalisasi pada lembaga pendidikan baik yang bersifat madrasah maupun pesantren sebagai penangkal gerakan radikal yang mengatasnamakan agama islam.

\section{Sejarah Berdiri SMK al-Azhar Menganti}

Pendirian Sekolah Menengah Kejuruan (SMK) al Azhar dimulai sejak PP. Darul Ihsan ingin mengembangkan lembaga pendidikan yang sudah ada. Dimana sebelumnya, PP. Darul Ihsan ditunjuk oleh pemerintah Kab. Gresik sebagai salah satu SMK mini yang menjalankan dua program keahlian semata. Sebagaimana tercatat di dapo.dikdasmen.kemendikbud, proses pengajuan pendirian SMK al Azhar dimulai pada tahun 2007, lalu mendapatkan surat izin pendirian sekitar tahun 2012. Kendati, sebagaimana sudah disebutkan sebelumnya, proses pembelajaran dan pendidikan vokasi ini sudah dijalankan pada tahun 2008-an. Setelah pengajuan pendirian dilayangkan ke pemerintah, kondisi mutaakhir sekolah ini sudah memiliki lima program keahlian, yaitu:

a. Teknik Komputer dan Jaringan (TKJ)

b. Teknik Pemesinan (TPM)

c. Teknik Kendaraan Ringan (TKR)

d. Rekayasa Perangkat Lunak (RPL)

e. Teknik Instalasi Tenaga Listrik (TITL)

Tahun 2019 SMK al Azhar akan memiliki program baru dan pemanfaatan fasilitas baru, yakni Balai Latihan Kerja. Dengan keberadaan BLK ini, proses pendidikan vokasi diharapkan lebih bermanfaat dan menunjukkan tajinya sebagai pendidikan yang menyiapkan para siswanya untuk membangun dan menumbuhkan perekonomian masyarakat, baik itu di sekita menganti, ataupun Kab. Gresik secara luas. (Dokumentasi: SMK al-Azhar Menganti) 
2. Visi dan Misi SMK Al-Azhar Menganti

a. Visi SMK Al-Azhar Menganti: Terwujudnya Insan Yang Mantap Imtaq dan Unggul Iptek

b. Misi SMK Al-Azhar Menganti: Menjadikan Lembaga Pendidikan Islam Profesional Melalui Peyenlenggaraan Pendidikan Yang Integral

3. Penerapan Pendidikan Aswaja (Ke-NU-aN) dalam Menangkal Faham Radikalisme

Penerapan pendidikan Aswaja (Ke-NU-an) dalam menangkal faham radikalisme di SMK alAzhar Menganti, sangatlah beragam, sebagaimana beberapa hasil wawancara. Hasil wawancara dengan kepala sekolah SMK al-Azhar Bpk. A. Ihksan memaparkan tentang penerapan pendidikan Aswaja (Ke-NU-An) sebagai berikut:

"Penerapan pendidikan Aswaja di SMK al-azhar dilaksanakan dalam berbagai bentuk. Memasukkan aswaja ke dalam kurikulum sekolah sebagai muatan lokal yang sangat diutamakan sebelum muatan lokal bahasa Jawa. Dalam pelajaran Aswaja di sekolah kami menggunakan Lembar Kerja Siswa (LKS) sebagai salah satu perangkat pendukung pembelajaran yang di koordinir langsung dari lembaga Ma' arif NU Gresik. Melaksanakan seminar Aswaja yang dilakukan rutin setiap tiga bulan sekali dengan menghadirkan narasumber dari tim Aswaja center, lembaga dakwah Al Azhar, dan beberapa pakar Aswaja (Ke-NU-An) tingkat nasional, H. Sururi, MM (Ketua Pergunu Jatim) dengan harapan semakin mampu menguatkan pendidikan dan nilai nilai Aswaja (Ke-NU-an). Dengan menguatkan pendidikan dan nilai nilai aswaja (ke-NU-an), maka secara otomatis akan terkikislah faham radikalisme. Melakukan apel pada setiap pagi, yang di dalamnya diselipkan pemahaman terhadap materi aswaja (Ke-Nu-an). Selanjutnya yaitu penerapan secara langsung dengan melakukan Amaliah Aswaja Nahdiyyyin dalam kegiatan rutin harian, yaitu diawali sebelum masuk kelas diadakan sholat Dhuha, sholat hajat dilanjutkan dengan dzikir dan doa bersama serta penguatan 4 pilar utama dalam belajar: niat, yakin, syukur, ikhlas. Karena dari empat pilar tersebut jika kita gali lebih dalam akan menjadi benteng dalam menangkal faham radikal." (Wawancara, 8 Desember 2018)

Gambar 2. Seminar ASWAJA (Ke-NU-an) dalam Menangkal Faham Radikalisme

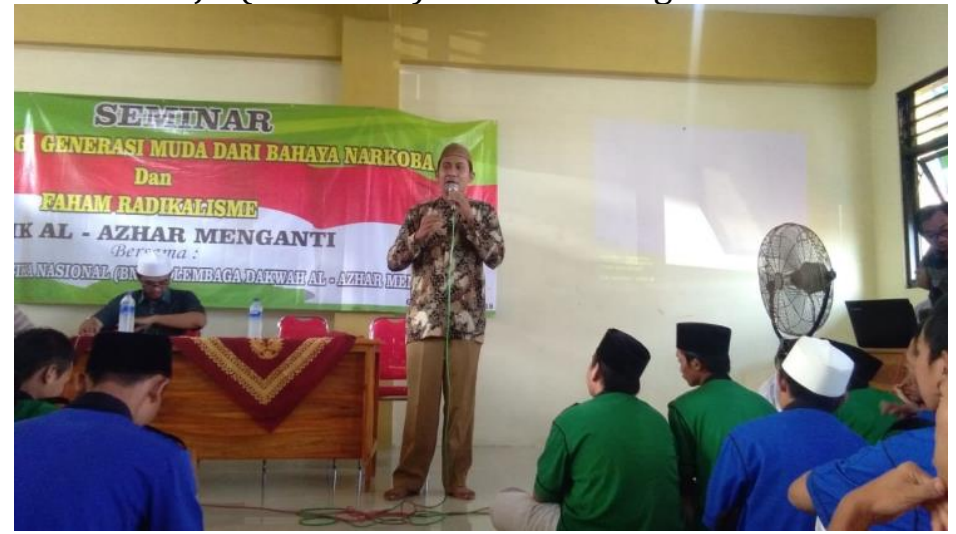

Sumber: (Dokumentasi SMK al-Azhar Menganti)

Sejalan dengan pemaparan dari Bpk. Akhmad Ikhsan, hal senada juga di sampaikan dari wakil Kurikulum, Bpk. Mustain tentang Penerapan pendidikan Aswaja (Ke-NU-an) dalam menangkal faham radikalisme di SMK al-Azhar Menganti yaitu:

"Penerapan pendidikan Aswaja yang dilakukan pada sekolah kami, adalah memberlakukan mata pelajaran Aswaja annahdliyah sebagai muatan lokal. Selain itu kegiatan keaswajaan di sekolah kami sangat di utamakan, seperti memberlakukan seminar keaswajaan dari awal di terima masuk sekolah kami. Selain itu kegiatan yang wajib diikuti adalah agenda pagi yaitu sholat dhuha dan hajat secara berjamaah. Selain itu pendidikan keaswajaan dilakukan melalui seminar-seminar keaswajaan yang di bentuk oleh Badan Esekutif Siswa (BES) maupun yang di agendakan oleh pihak kurikulum. Semua ini adalah bentuk konsistensi sekolah kita dalam menguatkan faham Ahlusunnah Wal Jama'ah (Ke-NU-An) sebagai bentuk penolakan terhadap faham radikal yang saat ini berkembang di Negara Indonesia (Wawancara, 10 Desember 2018).

J-PAI: Jurnal Pendidikan Agama Islam

Vol. 5 No. 1 Juli-Desember 2018

Homepage: http://ejournal.uin-malang.ac.id/index.php/jpai/ 
Pendidikan Aswaja (Ke-NU-an) memang menjadi aset utama di SMK al-Azhar Menganti, sebagaimana pemaparan dari guru mata pelajaran aswaja Bpk. Mukhlis, menjelaskan:

"Pendidikan Aswaja di sekolah ini menjadi sebuah keharusan, pertama karena lembaga ini berdiri pada yayasan pondok pesantren darul ihsan dengan faham Ahlusunnah Wal Jama'ah anNahdliyyah (NU) maka seluruh siswa mempunyai keharusan dalam memahami aqidah Ahlusunnah Wal Jama'ah anNahdliyyah. Kedua, pendidikan aswaja tidak hanya di masukkan lewat mata pelajaran. Seperti keberadaan mata pelajaran aswaja, yang kebetulan kami ampuh. Karena selain itu kita juga menerapkan melalui seminar-seminar yang di buat oleh pihak sekolah, ini diwajibkan untuk diikuti siswa. Tidak berhenti disitu, karena kita sebagai pendidik juga mendapat ruang untuk mengikuti seminar keaswajaan yang diberikan oleh pihak yayasan. Jadi, kita sebagai guru juga wajib belajar tentang keaswajaan lebih mendalam. Penerapan pendidikan aswaja lainnya adalah dengan memberlakukan apel pagi setelah sholat dhuha. Karena pada apel pagi terdapat penanaman aqidah Ahlusunnah Wal Jama'ah anNahdliyyah (NU) yang diberikan oleh pihak sekolah (wawancara, 14 Desember 2018).

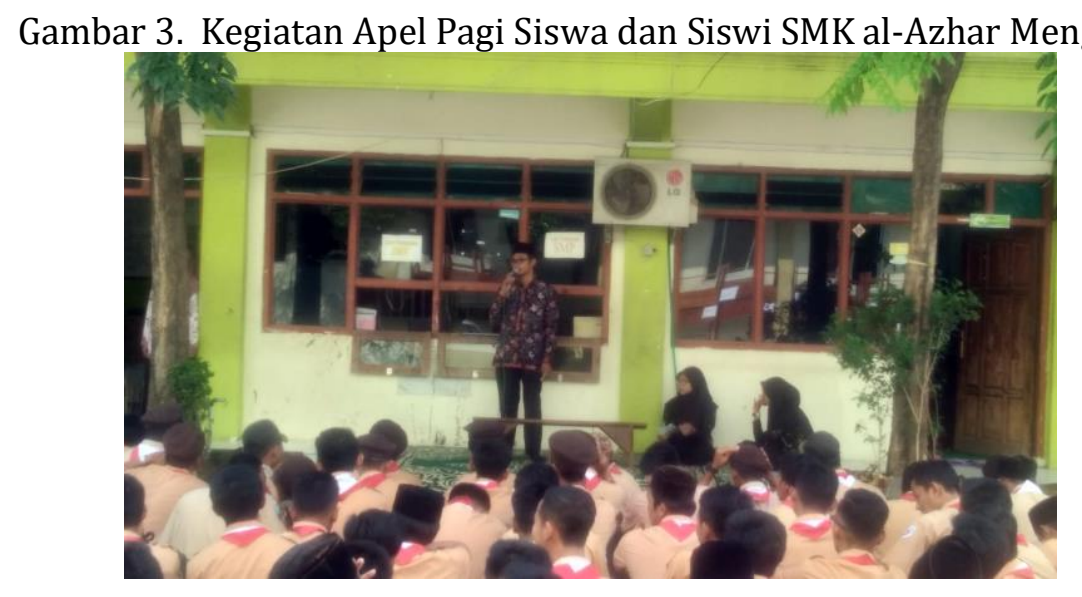

Sumber: (Dokumentasi SMK al-Azhar Menganti)

Pemaparan selain dari pihak sekolah, tentang penerapan pendidikan Aswaja (Ke-NU-An) di SMK al-Azhar Menganti, dari salah satu siswa dan anggota BES SMK Al-Azhar menganti, yaitu Sdr. Ade:

"Pendidikan Aswaja di sekolah kita sangat beragam, mulai dari adanya agenda seminar yang di lakukan setiap 3 bulan sekali, adanya mata pelajaran Aswaja di jam formal. Serta seluruh amaliyah keseharian yang dilakukan di sekolah kita, dapat dipastikan semua adalah amaliyah aswaja (NU), seperti pembacaan maulid diba', istighosah setiap pagi dan setiap hari jum'at, ziarah ke makam pendiri NU sebagai agenda tahunan di sekolah kita (Wawancara, 15 Desember 2018).

Kesimpulan beberapa hasil wawancara di atas, dapat dijadikan sebuah jawaban dari rumusan masalah pertama yaitu tentang keberadaan penerapan pendidikan aswaja (Ke-NU-an) dalam menangkan faham radikalisme di SMK Al-Azhar menganti Gresik, menjadi beberapa bagian:

1. Memasukkan pendidikan Aswaja ke dalam kurikulum sekolah sebagai muatan lokal yang sangat diutamakan sebelum muatan lokal bahasa jawa.

2. Melaksanakan seminar Aswaja dari pihak sekolah dan BES yang dilakukan rutin setiap tiga bulan sekali dengan menghadirkan narasumber dari tim Aswaja center, lembaga dakwah $\mathrm{Al}$ Azhar, dan beberapa pakar Aswaja (Ke-NU-an) tingkat nasional.

3. Pemahaman terhadap materi aswaja (Ke-Nu-an) diselipkan pada setiap Apel pagi.

4. Menerapkan Amaliah Aswaja (Ke-NU-an) dalam kegiatan rutin harian. yaitu diawali sebelum masuk kelas diadakan sholat Dhuha, hajad, pembacaan diba', istighosah serta ziarah ke makam pendiri NU sebagai agenda tahunan. Serta penguatan 4 pilar utama pesantren, yaitu: Niat, yakin, syukur, ikhlas. Sebagai benteng dalam menangkal berkembangnya faham radikal. 
Dari hasil penelitian ini menunjukkan bahwa pendidikan Aswaja (Ke-NU-an) di SMK AlAzhar, mempunyai beberapa cara dalam menerapkan pendidikan aswaja (Ke-NU-An) dalam menangkan faham radikalisme di sekolah formal yaitu SMK Al-Azhar menganti Gresik. Karena dengan banyaknya cara tersebut meminimalisir kebosanan siswa dalam mendalai pendidikan Aswaja. Melihat peran signifikan pendidikan Aswaja dalam menangkan faham radikalisme, juga terdapat hasil penelitian Wahyudin tentang pendidikan aswaja sebagai upaya menangkal radikalisme (Wahyudin, 2017) dan hasil penelitian Naim tentang pengembangan pendidikan aswaja sebagai strategi deradikalisasi (Naim, 2015) menyebutkan bahwa pendidikan Aswaja memuat nilai-nilai luhur: tawasut, tawazun dan tasamuh. Dengan menanamkan nilai-nilai Aswaja tersebut diharapkan dapat membentuk pribadi yang berkarakter inklusif dan menjungjung tinggi toleransi. Hal senada juga di sampaikan oleh suhatno pada artikel, yang menjelaskan bahwa muhammadiyah dan $\mathrm{NU}$ adalah organisasi yang menjadi potret islam moderat di Indonesia (Suharto, 2014).

\section{Faktor Penghambat dalam Menerapkan Pendidikan Aswaja (Ke-NU-An)}

Dalam penerapan pendidikan Aswaja (Ke-NU-an), tidak dapat di pungkiri terdapat beberapa hambatan di lapangan, tak lain hambatan yang di alami pada SMK Al-Azhar Menganti Gresik.

Terdapat beberapa hambatan dalam pendidikan Aswaja (Ke-NU-an) SMK Al-Azhar Menganti Gresik, hasil wawancara dengan Bpk. Akhmad Ikhsan selaku kepala sekolah:

“....Penghambatnya adalah kurangnya guru pendukung dalam pemahaman Aswaja (Ke-NUan) seperti guru fiqih, akidah, tafsir hadis, SKI, SKIA dan beberapa guru lain yang kurang memahami betul doktrin Aswaja yang sesuai dengan faham Aswaja Nahdliyyin (Ke-NU-an), sehingga untuk memberikan pandangan serta pemikiran yang sepaham dengan Aswaja Nahdliyyin (Ke-NU-an), hanya dimiliki oleh sebagian kecil dari guru yang ada. Hal inilah yang menjadikan yayasan mengadakan pendalaman keaswajaan (Ke-NU-an) bagi para guru. Banyaknya buku-buku diluar faham Aswaja Nahdliyyin (Ke-NU-an), yang mengatas-namakan Aswaja (Ke-NU-an) padahal doktrin dan pemikiran mereka bertentangan dengan doktrin Aswaja Nahdliyyin (Ke-NU-an). Perkembangan media sosial dan internet yang menjadi magnet terbesar para siswa inilah faktor tersulit guru dalam menangkal antara media pro radikal dan media pro Aswaja Nahdliyyin (Ke-NU-An). Karena Kelompok yang mengatasnamakan Aswaja namun berfaham radikal justru lebih aktif dan lebih menguasai dunia maya dan media sosial, sehingga setiap kali kita mengakses tentang pemikiran Aswaja, yang muncul justru pendapat dan tulisan mereka yang mengaku Aswaja tetapi doktrinnya dan kredonya bertolak belakang dengan doktrin aswaja. Banyaknya buku yang beredar di semua kalangan tentang Aswaja justru sebagian besar adalah yang berasal dari mereka. Termasuk kurang adanya minat baca tersebut dikarenakan sarana prasarana pendukung tersebut sangat lemah Baik dalam bentuk ketersediaan buku maupun tempat baca." (Wawancara, 8 Desember 2018)

Selain pemaparan dari Bpk. Akh. Ikhsan, peneliti juga mendapatkan pemaparan hasil wawancara langsung dari Bpk. Mustain, tentang faktor penghambat dalam menerapkan pendidikan Aswaja (NU) di SMK al-Azhar menganti, yang meliputi:

“...faktor penghambat yang sangat nampak, adalah banyaknya propagandamelalui media sosial, sehingga mudah diakses oleh para siswa. Karena peran media sosial ini sudah tidak dapat di tolak di era milenial saat ini sehingga siswa kadang lebih mudah menerima apa yang disampaikan dimedia sosial seperti maraknya ustad-ustad baru yang berhamburan di youtube, instagram dan twitter, menjadikan siswa percaya, sehingga tanpa harus mengecek ulang terlebih dahulu dengan ahlinya terutama ahli aswaja (NU). Selain dari pada itu hambatannya adalah kurangnya pendukung ketika di tengah masyarakat. Serta kurangnya literatur yang dapat di jangkau oleh para siswa karena banyak literatur yang di dominasi oleh kaum radikal. Hambatan lainnya yaitu para siswa yang kurang berminat dalam memahami tentang materi Aswaja (NU). Namun kita para guru selalu mencari solusi terbaik dalam mengawal aqidah Aswaja (Ke-NU-An)." 
Pemaparan senada tentang faktor penghambat dalam penerapan pendidikan aswaja (KeNU-An) juga di sampaikan oleh Bpk. Akhmad Muklis, selaku guru mata pelajaran Aswaja, sebagai berikut:

"Faktor penghambat yang sangat Nampak adalah peran besar media sosial, yang di dominasi oleh faham-faham radikal, selain itu juga banyaknya buku-buku pelajaran yang sudah terkontaminasi dengan pemikiran radikal, doktrin inilah yangcepat melekat pada diri siswa. Selain itu para siswa kurang berminat dalam membaca buku-buku, apalagi buku tentang faham Aswaja (Ke-NU-An). Penghambat nyata lainnya adalah siswa kurang berminat dalam mendalami faham Aswaja (Ke-NU-An) apalagi ketika di dalam kelas. Jadi, tugas guru Aswaja wajib mampu mendesain sebaik mungkin pelajaran Aswaja, sehingga siswa mempunyai minat yang lebih dalam mempelajari faham aswaja (Ke-NU-An).”

Dari beberapa hasil wawancara di atas, dapat disimpukan dari rumusan masalah kedua, yaitu tentang beberapa faktor penghambat penerapan pendidikan Aswaja (Ke-NU-an) dalam menanangkal faham radikalisme di SMK al-Azhar Menganti Gresik, karena tidak dapat dipungkiri masih perlunya pengembangan dalam dunia pendidikan, sebagai catatan terdapat 6 faktor penghambat, yaitu:

1. Kurangnya dukungan dari guru mata pelajaran lain, di karenakan minimnya pemahaman tentang Aswaja Nahdliyyin (Ke-NU-an).

2. Banyaknya buku-buku diluar faham Aswaja Nahdliyyin (Ke-NU-An), namun mengatasnamakan Aswaja (Ke-NU-An).

3. Semakin berkembangnya faham radikal, melalui media sosial, seperti you tube, twitter dan instagram yang menjadi magnet terbesar para siswa ddalam kehidupan sehari-hari.

4. Banyaknya buku yang mengatasnamakan Aswaja, namun di dalamnya justru bertolak belakang dengan faham Aswaja (Ke-NU-an).

5. Kurangnya minat baca pada diri siswa, dikarenakan sarana prasarana pendukung tersebut sangat lemah baik dalam bentuk ketersediaan buku maupun tempat baca.

6. Siswa kurang berminat dalam mendalami faham Aswaja (Ke-NU-an). dikarenakan desain pembelajaran yang masih classic.

\section{KESIMPULAN}

Pendidikan faham Ahlu Sunnah Wal Jama'ah Annahdliyyah (Ke-NU-An), adalah modal utama yang ditanamkan pada siswa-siswa SMK Al-Azhar Menganti sebagai upaya nyata dalam menangkal menjamurnya faham radikalisme pada dunia pendidikan, sebagaimana simpulan pada rumusan masalah pertama, tentang penerapan pendidikan Aswaja (Ke-NU-An) dilakukan oleh SMK Al-Azhar Menganti, yaitu: (1) Memasukkan pendidikan aswaja ke dalam kurikulum sekolah sebagai muatan lokal yang sangat diutamakan sebelum muatan lokal bahasa jawa, (2) Melaksanakan seminar Aswaja dari pihak sekolah dan BES yang dilakukan rutin setiap tiga bulan sekali dengan menghadirkan narasumber dari tim Aswaja center, lembaga dakwah Al Azhar, dan beberapa pakar Aswaja (ke-NU-an) tingkat nasional, (3) Apel pada setiap pagi, karena di dalamnya diselipkan pemahaman terhadap materi aswaja (ke-Nu-aN), (4)Menerapkan Amaliah Aswaja (ke-NU-an) dalam kegiatan rutin harian, yaitu diawali sebelum masuk kelas diadakan sholat Dhuha, hajad, pembacaan diba', istighosah serta ziarah ke makam pendiri NU sebagai agenda tahunan. Ditambah lagi dengan penguatan 4 pilar utama pesantren, yaitu: Niat, yakin, syukur, ikhlas. Sebagai benteng dalam menangkal berkembangnya faham radikal.

Dari beberapa penerapan yang diupayakan oleh pihak SMK al-Azhar Menganti, tidak menutup kemungkinan terdapat beberapa hambatan sebagaimana rumusan masalah kedua, yaitu tentang hambatan dalam menerapkan pendidikan Aswaja (Ke-NU-An) yaitu: (1) Kurangnya dukungan dari guru mata pelajaran lain, di karenakan minimnya pemahaman tentang Aswaja Nahdliyyin (Ke-NU-an), (2) Banyaknya buku-buku diluar faham Aswaja Nahdliyyin (Ke-NU-an), namun mengatasnamakan Aswaja (Ke-NU-an), (3) Semakin berkembangnya faham radikal, melalui media sosial, seperti you tube, twitter dan instagram yang menjadi magnet terbesar para siswa ddalam kehidupan sehari-hari, (4) Banyaknya buku yang mengatasnamakan Aswaja, namun di dalamnya justru bertolak belakang dengan faham Aswaja (Ke-NU-An), (5) Kurangnya minat baca 
pada diri siswa, dikarenakan sarana prasarana pendukung tersebut sangat lemah baik dalam bentuk ketersediaan buku maupun tempat baca, (6) Siswa kurang berminat dalam mendalami faham Aswaja (Ke-NU-An) dikarenakan desain pembelajaran yang masih classic.

\section{DAFTAR PUSTAKA}

Ahyar, M. (2015). Membaca Gerakan Islam Radikal dan Deradikalisasi Gerakan Islam. Walisongo: Jurnal Penelitian Sosial Keagamaan, 23(1), 1-26.

Arif, M. (2018). Revitalisasi Pendidikan Cinta Tanah Air di Pondok Pesantren Darul Ihsan Menganti Gresik. Jurnal Iqra': Kajian Ilmu Pendidikan, Vol. 3 (No. 2), 277-296. https://doi.org/https://doi.org/10.25217/ji.v3i2.369

Felay, G. (2003). Ijtihad Politik Ulama' Sejarah NU 1952-1967. Yogyakarta: LKIS Printing Cemerlang.

Hilmy, M. (2015). Radikalisme Agama Dan Politik Demokrasi Di Indonesia Pasca-Orde Baru. MIQOT: Jurnal Ilmu-Ilmu Keislaman, 39(2).

Husna, S., \& Yunus, M. (2016). Hasil-Hasil Muktamar Ke-33 Nahdlatul Ulama. Jakarta: Lembaga Ta'lif wan Nasyr PBNU.

Inbar, E., \& Frisch, H. (Eds.). (2008). Radical Islam and international security: challenges and responses. London; New York: Routledge.

Muctoboh, H., Sukawi, Z., Kholik, Asmaji, Shidiq, N., Mahfudz, ... Amin, Y. (2017). Pengantar Studi Aswaja An-Nahdliyah. Yogyakarta: LKIS Printing Cemerlang.

Muzadi, A. M. (2007). NU dalam Perspektif Sejarah dan Ajaran (Refleksi 65 Tahun Ikut NU). Surabaya: Khalista.

Naim, N. (2015). Pengembangan Pendidikan Aswaja Sebagai Strategi Deradikalisasi. Walisongo, Vol. 23(No. 1), 69-88.

Nasr, S. H. (2003). Islam, Agama, Sejarah dan Peradaban. Surabaya: Risalah Gusti.

Navis, A., Ramli, M. I., \& Anam, F. K. (2016). Risalah Ahlu Sunnah Wal Jama'ah dari Pembiasaan Menuju Pemahaman dan Pembelaan Akidah Amaliah NU. Surabaya: Khalista.

Raco, J. . (2010). Metode Penelltlan Kualltatlf Jenis, Karakteristik, Dan Keunggulannya. Jakarta: Grasindo.

Ramli, M. I. (2011). Pengantar Ahlu Sunnah Wal jama'ah. Surabaya: Khalista.

Robinson, K. M. (2009). Gender, Islam, and democracy in Indonesia. New York, NY: Routledge.

Sahrasad, H., \& Chaidar, A. (2017). Fundamentalisme, Terorisme Dan Radikalisme Perspektif Atas Agama, Masyarakat Dan Negara. Indonesia: Freedom Foundation \& Centre for Strategic Studies - University of Indonesia.

Suharto, T. (2014). Gagasan Pendidikan Muhammadiyah dan NU Sebagai Potret Pendidikan Islam Moderat di Indonesia. Islamica: Jurnal Studi Keislaman, Vol. 9(No. 1), 81-109.

Umar, A. R. M. (2010). Melacak Akar Radikalisme Islam di Indonesia. Jurnal Ilmu Sosial Dan Ilmu Politik, 14(2), 169-186.

Wahyudin, D. (2017). Pendidikan Aswaja Sebagai Upaya Menangkal Radikalisme. Dinamika Penelitian: Media Komunikasi Sosial Keagamaan, Vol. 17(No. 2), 291-314.

Waskito, A. M. (2012). Mendamaikan Ahlus Sunnah Di Nusantara Mencari Titik Kesepakatan antar Asy'ariyah dan Maturidiyah. Jakarta: A-Kautsar.

Zuhri, A. M. (2010). Pemikiran KH. M. Hasyim Asy'ari tentang ahlu sunnah wal jama'ah. Surabaya: Khalista. 